\title{
A human RNA polymerase II complex associated with SRB and DNA-repair proteins
}

Edio Maldonado, Ramin Shiekhattar, Michael Sheldon, Helen Cho, Ronny Drapkin, Paula Rickert, Emma Lees, Carl W. Anderson, Stuart Linn \& Danny Reinberg

Nature 381, 86-89 (1996)

FIGURE 1 is reproduced again here because the original image reproduction was incorrect and masked critical bands in the gels.

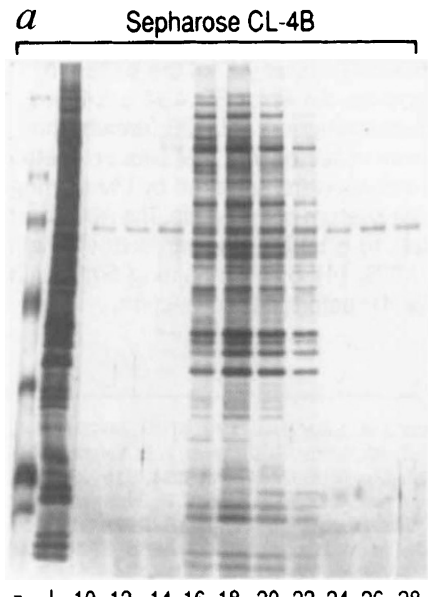

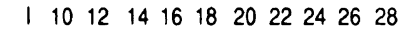

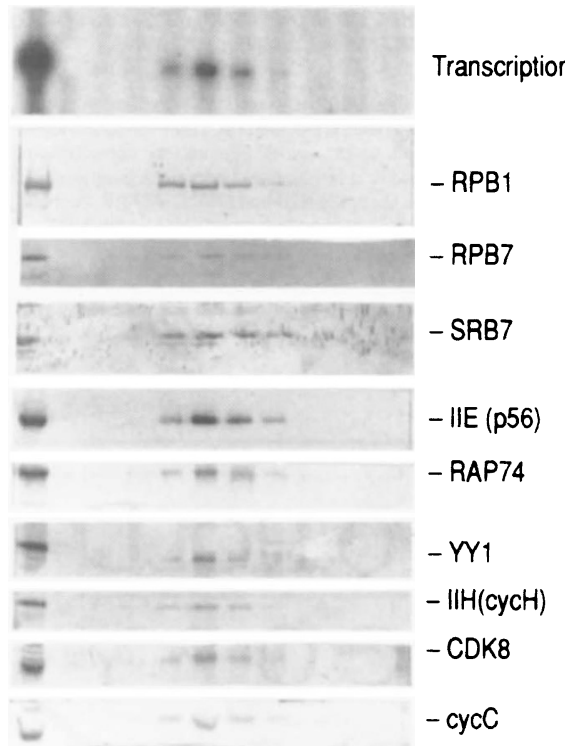

Silver

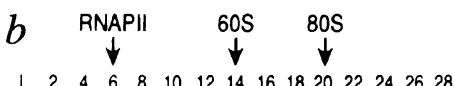

$\begin{array}{llllllllllllll}2 & 4 & 6 & 8 & 10 & 12 & 14 & 16 & 18 & 20 & 22 & 24 & 26 & 28\end{array}$
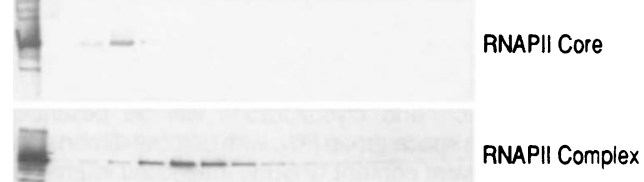

NE

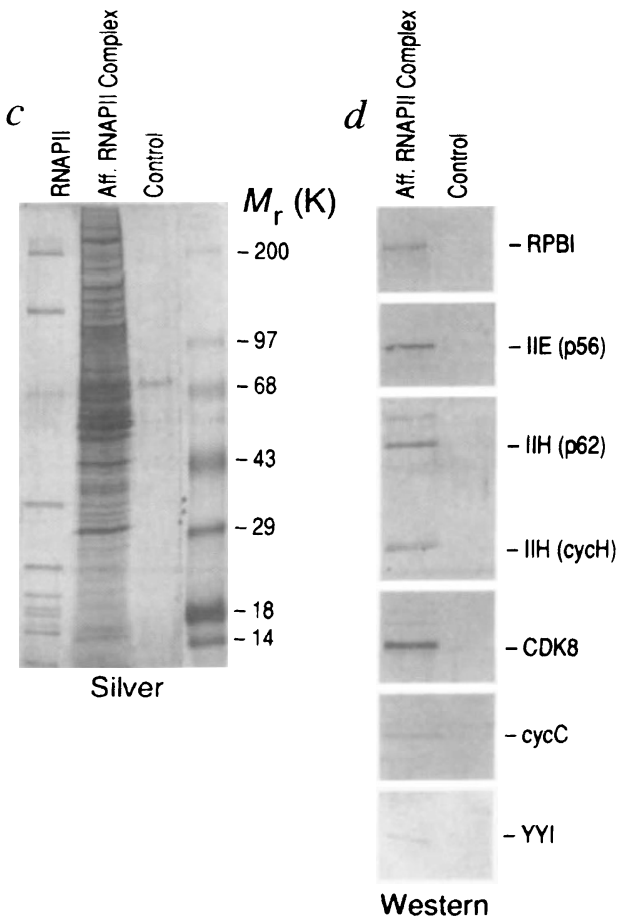

FIG. 1 